\title{
Cross-Strait Relations-From the Sole China, Two Chinas and the Greater China
}

\author{
David J. Sarquis \\ Universidad del Mar (UMAR), Huatulco, Mexico \\ Wei-Chiao Ying \\ Tecnológico de Monterrey, Monterrey, Mexico
}

\begin{abstract}
This article analyses the bilateral relations across the Taiwan Straits, between the People's Republic of China (PRC) and the Republic of China (ROC) tracing developments from the end of WWII to date, considering the dispute over the legitimacy of the representation of the Chinese people as a whole. We attempt to draw a thorough picture of how relations between the "two Chinas" evolved in the historical frame of the Cold War and the post-Cold War period, in order to suggest the prospective for the near future. We conclude that the concept of the Greater China is no longer restricted to the economic/commercial sphere but it can also be extended to all aspects of life in the Chinese-speaking region. While the competition between the two Chinas remains tough, thanks to the characteristic notion of "harmony but not uniformity" of the Chinese identity, the door to a peaceful reunification is open.

Keywords: Taiwan Straits, One-China Policy, the Greater China, Chinese identity
\end{abstract}

\section{Introduction}

When people talk about China today, in different parts of the world, most bring to mind almost instantly the big giant that is emerging as a world power in the 21th century: the People's Republic of China (PRC). The "World Factory", they say, although the fact is that many major multinational enterprises, which have invested in China for decades since the 1978 economic reforms, is now even more interested in increasing the opportunities to boost their sales in the Chinese massive domestic market. They have proposed ambitious plans to expand in the PRC, considering the high sales figures and market opportunities they are bound to find once established there. In order to achieve their goals in the PRC, companies like IBM, Amazon, and Microsoft have complied with the Cybersecurity Law by forming partnerships with local companies to offer cloud computing services based in the PRC and Apple has even gone one step further by announcing its plans to open a new data center over there. No doubt, the PRC is being transformed from a manufacturing base to a consumer society that is becoming as attractive as any major developed economy in the West, perhaps even more. Thus, China has become a very attractive pole of development that the rest of the world is watching carefully, some with more fear than hope.

David J. Sarquis, Ph.D. in International Relations, professor at the Institute of International Studies "Isidro Fabela", Universidad del Mar (UMAR), Huatulco, Mexico.

Wei-Chiao Ying, Ph.D. candidate, B.A. in Business Management, Graduate School of Social Science and Humanities, Tecnológico de Monterrey, Campus Monterrey, Mexico. 
Given the fact that when multinational corporations outline their investment and marketing strategies in China, they set up a "Greater China" headquarter instead of focusing exclusively in mainland China, the following question is raised: Why the "Greater China" is an economic reality, but has struggled to become a political reality in the PRC-ROC case? In this article, we recognize this as our main research question and in order to provide an answer, we look at:

(a) How and why Taiwan became internationally recognized as the legitimate representative of all China (until it was expelled from the UN in October 1971 in accordance with UN resolution 2758 of the General Assembly). This can be, at least in part explained by the general conditions of the Cold War.

(b) How the communist in mainland and the nationalists in Taiwan developed a sense of separate identities.

(c) At the end of the Cold War, we had two political entities that felt alienated from each other, but were struggling for the same cause: True representability of the Chinese people.

(d) The new globalized order allowed for the development of an economic link between the "two Chinas", even though, the political question was still unresolved.

(e) This was important because, if the economic links grew strong, in the mid-term, a political answer could also arise, given the mutual benefits of economic and cultural links based on the principle of "harmony but not uniformity".

We conclude that the emergence of two Chinas was more of a historical contingency aggravated by the Cold War, than a natural occurrence in the process of configuration of the regional scenario of South-East Asia following the Westphalian model of national states, thus a solution to this problem might be envisioned from the perspective of the growth and consolidation of the Greater China in economic and cultural terms, which can make a political solution more palatable to the parties involved.

\section{China as a Civilization State}

The Chinese have fought hard to earn their place in the Westphalian system of international relations, which they entered forcefully during the 19th century. They came from a long-term tradition of political organization, noticeably different from the European model of national states. They were better understood as a "civilization-state" (Pye, 1990; Jacques, 2011) but under the influence of the European powers, they had to adapt to the conditions of the Eurocentric model, and almost 200 years later, they now emerge as a rising world power, not necessarily in the same European tradition under which they joined the international system originally almost two centuries ago. This is not a minor achievement. China was almost fragmented to pieces during the process of absorption into the Westphalian system. Nevertheless, the Chinese managed to survive and successfully learned the game of politics Western style, which they are now playing at an advantage, supported by the everlasting nature of a civilization state. More than two decades ago, this nature was interpreted as a disadvantage for China; one that led to frustration in the transition to a modern nation state, as Pye (1990) put it straight forward: "China is a civilization pretending to be a state". Today, China has proved to be a "civilizational state", a hybrid of nation-state and civilization-state (Zhang, 2016), which conducts a grand experiment on its own path to adapt to a nation-state while maintaining its own characteristics as a civilization. A civilization, as we see, is determined by common social practices and values amongst groups of people of different ethnic backgrounds, language, or creed, without the need of a political structure to bind them together. It is not necessarily limited by national borders, but by common beliefs and it extends in time as long as those 
beliefs play a role in shaping the identity of the people committed to them. Christendom or the Muslim Umma of the Middle Ages might be good examples. A civilization-state develops its own political structure, but it is not necessarily the same as the characteristic structure of the national state, in the case of China:

The state is seen as the embodiment, guardian and defender of Chinese civilization. Maintaining the unity, cohesion and integrity of Chinese civilization-of the civilization-state-is perceived as the highest political priority and is seen as the sacrosanct task of the Chinese state. Unlike in the West, where the state is viewed with varying degrees of suspicion, even hostility, and is regarded, as a consequence, as an outsider, in China the state is seen as an intimate, as part of the family, indeed as the head of the family; interestingly, in this context, the Chinese term for nation-state is "nation-family". (Jacques, 2011)

The status quo of the relations between Taiwan Strait is a strong reflection of what it means to be a "civilizational state". The original and provisional settlement based on the 1992 Consensus and the endurance of the Chinese identity in the context of a Greater China stands for that.

The notion of a Greater China as proposed in this paper goes beyond the basics of regionalization theory, because we are not looking at an integration process solely based on convenient characteristics to optimize the use of resources or benefit the most from geographic conditions or the use of existing infrastructure; not even the advantages of complimentary scale economies. We find the term "region" rather ambiguous in that regard, even though it has been widely used in different disciplines (Claval, 1987), such as geography, anthropology, sociology, economy, or international relations, where a host of different authors suggest what they consider to be the proper use of the term, from their own perspective. Even though there might be some solid arguments to speak of the Greater China from the perspective of regionalization, we believe the main argument for such concept derives from the notion of a civilizational rather than a national state. So, in spite of the advantages that regionalization theory might offer in this case, we believe it falls short from the idea of a civilization to integrate a group of people and the geographical space they share.

Before becoming the target of systematic concerns, regional studies sought, above all, to identify specificities, curiosities and descriptions of the most different parts of the globe (Claval, 1974). From the mid-eighteenth century several forms of description, classification and analysis techniques have been created without the intention to develop a more "scientific" point of view about the term region. These concerns have become more common in the early twentieth century, when the systematization of a "regional geography" began to take its first steps, both in Europe and in the United States (Whitlessey, 1954); three were the main authors who developed the first theoretical definitions on the regional phenomenon: Alfred Hettner, in Germany, Vidal de la Blache, in France, and A. J. Herbertson, in Great Britain (Duarte, 1980). Organized by Betioli Contel (2015).

As we can see, regionalization theory can be used both to justify the integration of an area according to different criteria, and to fragment it, so, for example, some authors believe the U.S. can be culturally divide in a dozen or so different regions. A civilization, from our point of view, is more a matter of values and principles underlying socio-political behavior, and this is what we have in mind when talking about the Greater China.

\section{The Sole Legitimate Representative of All China}

China is currently becoming a leading power in the game of international politics and it is offering to reestablish the rules of international order. However, it still has to overcome the challenges of reunification of a single Chinese national state (Western style) because the PRC is not the only political entity claiming to be China in the world today. As Hung and Kuo (2010) state: 
The path along which the Qing Empire transformed into the People's Republic of China as a modern nation-state is perhaps the most peculiar in the world history of nation formation. While most other multinational world-empires, such as the Ottoman and Austro-Hungarian, disintegrated into multiple relatively homogenous nation-states in their transition to modernity, China managed to transform nearly all of its imperial territory into a singular nation-state despite the cultural and ethnic heterogeneity of this geographical space. (Hung and Kuo, 2010, pp. 317-318)

By "nearly all of its imperial territory", the two authors refer to the fact that the sole China split into two different political entities when the Chinese civil war ended in 1949. The legendary Mao Zedong founded the People's Republic of China (PRC) in 1949 after winning a long devastating civil war, and the Republic of China (ROC) founded since 1912 by the national martyr Sun Yat-Sen after imperial China collapsed. The nationalist government that ruled ROC under Chiang Kai Shek retreated to Taiwan after losing the civil war, and established itself there ever since, giving birth to the idea of "two Chinas". The split entertained the interests of the two world powers much more than those of the Chinese people.

ROC as the representative of the Free China, occupied the seat of the Chinese at the UN Security Council for over two decades, and thus supposedly represented the Chinese people as a whole, since they did not recognize the communists as a legitimate government. After political maneuvering on behalf of American interests, the UN accepted the PRC as a member in 1971 and replaced ROC as a permanent member in the Security Council. Chinese interests, on the whole were clearly viewed under the light of superpower interests.

On one hand, recognition by the UN was a milestone for the PRC, although most of its citizens did not realize the importance of the change of role due to the traumatic Cultural Revolution, which lasted until 1976 when Mao died. It was also a breakthrough in the sense that it marked a major change of the world scenario captured in frame of the Cold War. The division between the Communist World and the Free World was no longer definite, since the great powers of the Free World granted their recognition to Communist China as the sole legal representative of all China. On the other hand, the two-decade long fiction of Taiwan representing all China officially broke, the ROC mourned as people there felt they had been abandoned by the international community, but it was also a turning point for the youngsters in Taiwan to start questioning about their Chinese identity, even though up to date the name of the country remains Republic of China and the legal fiction of separate statehood remains a topic of debate.

\section{The Merger of a Greater China}

In the Chinese language, the modern usage of the concept the Greater China first appeared in a Taiwanese journal in 1979. It advocated the creation of a "Chinese Common Market" that would link Taiwan, Hong Kong, Macao, Singapore, and the Chinese Mainland. This was the result of the post-Mao reforms in Mainland, and it intended to highlight the prospects that a similar growth might occur in the commercial relations between Taiwan and Chinese Mainland following the imperatives of the globalizing trends (Harding, 1993). The PRC, however, has always rejected the idea that Taiwan, Hong Kong, or Macao were separate political entities. From their point of view, they were patches of land forcefully stripped from Chinese sovereignty, to which they should eventually be reintegrated, even though the Communist government was clearly aware of its own limitations to do this in a forceful manner.

Whereas, in the English language, when The Economist mentioned in 1987 that Taiwan might eventually join in a "Greater China Confederation" (The Economist, 1987), it opened the door to discussion about the possibilities of a political reunification, although the concept of the Greater China was always more common to 
describe the commercial ties between the main Chinese economies, in line with the notion of a world-economy put forward by Wallerstein (1976, pp. 229-233). From this point of view, political communities can only make sense in the context of the economic framework under which they operate. After the economic reforms of the late seventies, the PRC started to grow into the powerful engine that drives today the largest part of prosperity in South-East Asia, therefore compelling all the other economies in the region to gradually gravitate towards her.

In this century, the Greater China has become a firm commercial reality, but the light of a great political unification is still dim. Hong Kong and Macao were returned to the PRC respectively in 1997 from the British and in 1999 from the Portuguese and identify themselves as the Special Administrative Regions of the PRC. Will Taiwan step on a similar road-map or in an alternative direction? There is much to be discussed. The following historical overview provides us the grounds for further analysis.

\section{A Historical Overview}

\section{From 1945 to 1949}

When WWII came to an end in 1945, Taiwan was returned to the Republic of China as Japan surrendered. It was a dramatic year for Taiwan. After 50 years being a Japanese colony, many Taiwanese experienced an identity crisis when the Kuomintang (the Nationalist Party) sent troops to take over the island. First of all, the majority of the people did not speak mandarin. Japanese was the official language and the dialects (Min, Hakka, etc.) which originated from the south-eastern provinces in Mainland China that arrived with the islanders' ancestors dating from the early 17th century were widely spoken. Plus, the local indigenous groups were present and they preserve their own traditions and languages to date. We argue, however, that in spite of the Japanese colonization process, and because Japan itself was a Sinic state, Taiwan did not become totally alienated from its own Chinese legacy.

Second, the Kuomintang troops were not in their best conditions when they reached the Taiwanese shore. Most of them were traumatized by the eight-year-long Anti-Japanese War and found themselves physically and economically weak. The military leaders had a hard time maintaining the discipline and failed to build a good reputation from the very first contact with the islanders.

In the Chinese mainland, the Kuomintang had little time to savor the victory against the Japanese. The Civil war officially broke out between Kuomintang and the Chinese Communist Party (CCP) in 1946. Kuomintang hired and kidnapped countless troops from Taiwan and sent them to the battle fields in Chinese Mainland. Many of them were captured by the People's Liberation Army (under CCP) and later participated in the Korean War (Long, 2009). Throughout the civil war in Chinese Mainland, both Kuomintang and CCP either hired or kidnapped male civilians and sent them to battlefields. At the end of the war, when Kuomintang started to retreat to Taiwan, the officers and generals took along with them many soldiers who were not allowed to leave the troops and neither had a chance to notify their families about their departure to the island across the Strait. A new political reality was forged, against the background of the ancient Chinese civilization.

\section{From 1949 to 1971}

The general in command and also the president of the ROC, Chiang Kai-shek provisioned Kuomintang's failure in the civil war and ordered his son Chiang Ching-kuo to remove all the gold reserves from the Central Bank of Shanghai to Taiwan in January 1949 as part of the top secret retreat plans. The total value of the gold was 300 million USD, exactly equivalent to the loan that Mao Zedong asked from Stalin for the newly founded 
PRC later (Chen, 2011). Some 1.3 million mainlanders were uprooted to Taiwan throughout 1949, and most of them did not realize that it would be a four-decade farewell from their families in mainland. They settled down in Taiwan and recognized as "the new arrivers or people from outer provinces" to date. Meanwhile, the islanders, who identify themselves as "the natives or people from the original province" had a six-million population that year (Jiang, Mi, \& Zhang, 1996). Taiwan, despite the sudden population boost, thanks to the gold transported from the mainland, successfully avoided a currency crisis and stabilized the island's economy in the 1950's.

The USA was about to abandon Chiang Kai-shek and his Kuomintang based regime when he swallowed the bitter defeat by Mao Zedong. However, Mao was obliged to send a great number of Chinese troops across the Chinese-Korean border in 1950, right after the U.S. announced their participation in the Korean War and that fact twisted the ROC's fate. Mao had little choice but to do as Stalin wished due to the pending 300 million loans from the soviets to the Chinese. As a result, instead of focusing on "liberating" Taiwan from Kuomintang, Mao lost more than 100,000 soldiers, including his own son, in Korea and found it more difficult to launch a war cross the Taiwan Strait later when the U.S. 7th Fleet Detachment already set its base in the Taiwan's main harbor. Until then, from the point of view of international law, the Chinese question was a problem of government recognition, rather than state partition.

Mainland China, due to the lack of funds, the extensive territory and the aftermath of the war, launched the Great Leap Forward campaign in the late 1950's, which aimed at transforming the country rapidly from an agrarian society to a socialist and industrial society, but the policy turned out to be a complete failure that caused the Great Chinese Famine.

In order to centralize power and distract the people from the economic crisis, in the mid-sixties, Mao started the Chinese Cultural Revolution that put the PRC into a tragic 10-year-void regarding the mass destruction of Confucian teachings and values. Hundreds of thousands of academics were sent to labor camps, higher education institutions were forced to teach only political lessons, and it is still a taboo to discuss this topic openly in mainland China. Nevertheless, considering the ever worsening Soviet-Sino relations, U.S. President, Richard M. Nixon took advantage of the situation and decided to approach the leaders of the PRC in attempt to isolate the Soviet Union from its emerging neighbor. Apart from the ideological dispute between the Soviet Union and PRC, their conflicts escalated as the Sino-Soviet war broke out in March 1969 over the uninhabited island Treasure (Zhenbao) in the Ussuri River (Gao, 2007, p. 7). Amid the ever intensified Sino-Soviet conflicts, Nixon first signaled his interest in improving relations with PRC in his inaugural address on 20 January 1969, months later announced to lift part of the sanctions on travel and $\operatorname{trade}^{1}$ against the PRC, and by the end of the same year he also terminated regular 7th Fleet patrols in the Taiwan Straits (Lam, 2015, p. 54). Moreover, it was accepted by the UN in 1971 and immediately replaced the ROC as a member in the Security Council, leaving ROC in a virtual political limbo, basically sustained by American interests in the region.

\section{From 1971 to 1987}

With Henry Kissinger's help, President Nixon visited Mainland China in 1972 and it was a milestone in

\footnotetext{
${ }^{1}$ On 21 July 1969 the United States cancelled certain sanctions against the PRC and relaxed limitations on travel to China. In August 1969, Nixon lifted the travel and trade ban, allowing his Secretary of State William Rogers to signal interest in opening a dialogue. Crucially, in November 1969, he also terminated regular Seventh Fleet patrols in the Taiwan Straits (Lam, 2015, p. 54).
} 
the PRC's diplomatic history. Following the USA, Japan normalized its relations with PRC that same year. Finally, President Carter established official diplomatic relations with the PRC in 1978 and recognized it as the sole and legitimate China according to the One-China Policy still in place in U.S.-Chinese relations ${ }^{2}$, without entirely abandoning the ROC to its own fate.

The ROC lost its legitimate status in the UN and became ever more isolated by international society when the USA announced it would recognize the PRC and terminate the "Mutual Defense Treaty between the USA and the ROC". In 1979, the "Taiwan Relations Act" came into effect and relations between USA and the ROC were redefined. Despite the fact that it has been considered a controversial law, since the PRC considers the Act to be a major tool of the USA to interfere in China's domestic politics and the ROC complains about the unspecified promises that USA made to defend Taiwan's sovereignty, the Act remains unmodified since 1979, because it clearly suits American over Chinese interests. As for the international community, people were gradually accustomed to addressing the PRC as China and the ROC as Taiwan respectively, without having a deep knowledge or interest in the causes or consequences of the divide between the two governments.

Economically, both China and Taiwan took a great step forward in this period of time. In China, after Mao's death in 1976, Deng Xiaoping took over and introduced the economic reforms in 1978, which modified the practice of the socialist economy and opened the Chinese market to western capital. It was at this moment that China unveiled itself to the world. As for Taiwan, Chiang Ching-kuo became president of the ROC a couple of years after his father, Chiang Kai-shek passed away. He dominated the Ten Major Construction projects, which provided the platform for Taiwan to emerge as one of the Four Asian Dragons ${ }^{3}$.

\section{From 1987 to 1996}

For many Taiwanese/Chinese, 1987 was the most emotional year of their lives. When Chiang Ching-kuo lifted the Martial Law that had lasted for 38 years in the island, people were thrilled to see the release of the political prisoners jailed under the white terror, the right to form political parties (DPP [the Democratic Progressive Party] which advocates Taiwan's independence from China became legalized), and to enjoy the many other forms of freedom to come, including the right to visit mainland China. Heartbroken stories started to be told when families across the strait reunited in mainland China. Most people who were uprooted in 1949 could not find their parents' graves anymore; "everything has changed" literally, they claimed. An extreme case was the disappearance of a 1,500-year-old ancient town named Chun-an in Zhejiang Province. Thousands of mountains were submerged into the water due to the construction of a major dam in the area, what is left today are the thousands mountain peaks which look just like small islands. The Qiandao Lake ${ }^{4}$ (Thousand Island Lake) has been one of the most popular tourist attractions in south eastern China for several decades now.

\footnotetext{
${ }^{2}$ In spite of President Trump's threat to reconsider the One China Policy of his predecessors, no official move has been made to change the status of the relation with the PRC.

3 The Four Asian Dragons or The Four Asian Tigers are made up of four countries in East Asia-South Korea, Taiwan, Singapore, and Hong Kong. They all went through rapid growth by going through industrialization since the 1960s when TNCs looked for areas with cheap labor and low costs for other things. They are considered as the first generation of NICs. Japanese TNCs were among the first to seek new areas for their operations, so they chose their less developed neighbouring countries, particularly South Korea and Taiwan as a host nation for factories and manufacturing. Retrieved November 6, 2017, from http://developmentandglobalisation.weebly.com/the-asian-tigers.html.

${ }^{4}$ Qiandao Lake, also known as Thousand Island Lake, is a sprawling body of fresh water, covering $573 \mathrm{sq}$. km. The name comes from the fact that there are over a thousand islands in the lake. Qiandao Lake was created in 1959 when the valley at the base of the $\mathrm{Wu}$ Shi (Five Lion) mountain was flooded to create the Xin'anjiang Reservoir and Xin'an River hydroelectric station. Retrieved November 6, 2017, from http://www.uwphotographyguide.com/dive-qiandao-lake-china.
} 
In comparison to the overjoy of the Taiwanese, people in mainland China lived through one of the most dramatic incidents in contemporary Chinese history, the Tiananmen Square protests of 1989. Largely due to the economic reforms introduced by Deng Xiaoping and the consequent currency crisis that climbed to its peak in 1988, after months of protests and almost three weeks of hunger strikes organized by the students, on June 4th, Beijing announced the square would be evacuated and also the national wide protests would be ended. High casualties occurred in most of the major cities in mainland China, although there are no official records of casualties. There were mass demonstrations in the Chinese communities abroad, too, including Hong Kong and Taiwan. The ex-Singaporean Prime Minister Lee Kuan Yew expressed his support for Deng Xiaoping's decision, commenting in an interview that: "If I have to shoot 200,000 students to save China from another 100 years of disorder, so be it" (Lambert, Montagnon, \& Dawkins, 1999). The aftermath of Tiananmen Square protests is that until today, the EU and U.S. embargo on armament sales to the PRC remains in place, despite the protests from Chinese officials (Weitz, 2012). Furthermore, when people talk about China's human rights issues, a sense of mistrust is always in the air and the ghost of Tiananmen seem to hover in the air.

Relations between Taiwan and mainland China were tense, but remained cordial on the whole. Actually, the flow of Taiwanese tourists to mainland China, which had started towards the end of the eighties, did not show signs of diminishing.

Regarding the idea of "One China", an interesting Consensus was reached in 1992 by semi-official representatives across the Strait, which confirmed the status quo and affirmed the "Different Interpretations" regarding the One China Principle. It reads:

Concerning the meaning of "one China", the two sides of the Taiwan Strait adhere to the one China principle. But both sides ascribe different meanings to the term. The Chinese Communist authorities understand "one China" to mean the "People's Republic of China". They think that after reunification, Taiwan will be a "Special Administrative Region". We think that "one China" means the Republic of China, founded in 1912. Its sovereignty includes the whole of China. But its current jurisdiction is limited to Taiwan, Penghu, Kinmen and Matsu. Taiwan is part of China. But the Chinese mainland is also a part of China. (China Times Editorial, 2012)

From our point of view, this would indicate an implicit recognition of a common Chinese identity, defining a vast population in the area, divided by the question of the legitimacy of the government that should represent them.

In spite of the fact that during the nineties and the first decade of the new century the advocates of an independent Taiwan still held a strong position, the rapid development of the economy in mainland China helped develop economic ties that have made their option increasingly less realistic for many Taiwanese people during the last decade, although this does not necessarily mean a definite change of heart toward mainland China. The situation is still very complex and far from being satisfactorily resolved.

The 1992 Consensus is widely considered the base of the bilateral cross-strait relations today, although the advocates of independence in Taiwan argue about the legitimacy of such document, saying it was signed by semi-official representatives from the Chinese Communist Party and Kuomintang in private, so it can not represent the voice of the Taiwanese people. 
While progress was being made smoothly, the Qiandao Lake Incident ${ }^{5}$ that took place in 1994 involving the death of 24 Taiwanese tourists, six mainland Chinese crews, and two mainland Chinese tour guides added obstacles for the advancement of bilateral relations.

\section{From 1996 to 2008}

With the memory of the Qiandao Lake Incident and the threat of missiles ready to bomb Taiwan from the Chinese Mainland, the results of the first direct presidential election in 1996 were far from the appeal of Beijing, nevertheless, the crisis ended when two USA aircraft carriers approached Taiwan (Global Security.org, 2011).

The first directly elected ROC president, Lee Teng-hui was born under the Empire of Japan and the first Native person (not migrant from mainland China in 1949 nor a decedent) to become the ROC president and Kuomintang chairman. He was not welcomed by Beijing, since he was close to DPP and he promoted the Movement of "Taiwanization" (Horowitz \& Tan, 2005). After Lee Teng-hui was succeeded by Chen Shui-bian, a DDP presidential candidate in 2000, Lee was expelled from Kuomintang officially for supporting the newly founded Political Party, Taiwan Solidarity Union ${ }^{6}$ in public in 2001.

During the eight years DPP rule under President Chen Shui-bian, bilateral cross-strait relations were literally frozen. Beijing could not stand DPP's ideological values, which advocate for Taiwan's independence from the Chinese frame and they chose to confront each other in the toughest possible ways. First, Chen introduced the concept of "One Country on Each Side" during a visit to Tokyo in 2002, which denies Taiwan's role under the One China frame which was earlier reached by Kuomintang in the 1992 Consensus. Chen explained that "Taiwan is Taiwan, and China is China; we are different countries on each side of the strait". Second, when the epidemic SARS broke out in Canton province in mainland China, all the region was badly affected. It spread so fast, mainly due to Beijing's media censorship policy that people could not react to it properly in the first place. Furthermore, Beijing interfered with the vaccine distribution from the World Hygiene Organization to Taiwan arguing that since Taiwan is part of China, so the distribution work should be organized by Beijing. This episode served as nothing more than an incentive to strengthen the voice of Chen's "One Country on Each Side" within Taiwan. Last but not least, after a three-year-long discussion, Beijing passed the Anti-Secession Law in 2005 which is specifically directed to the bilateral cross-strait relations. It defines that mainland China and Taiwan belong to one China and the "Taiwan issue" is a residual problem of the Chinese civil war and it is an internal affair of China. Also, it legitimizes the right to conduct non-peaceful measures whenever there is a perceived threat of Taiwan's separation from China.

The cross-strait economic and cultural exchange was affected severely by the political turmoil. Everything from the co-celebration of the Chinese New Year to university exchange programs stopped. Tension was the

\footnotetext{
5 In April 1994, 24 Taiwanese tourists died on a visit to Qiandao Lake in mainland China. According to the initial Chinese reports on the deaths, the 24 tourists and eight mainland crew and guides on the Hairui pleasure boat were the victims of an accidental fire. An official in Zhejiang said initial investigations pointed to an explosion on the vessel; deaths had been caused by fire or drowning; there was no evidence of robbery and there had been "no abnormal wounds". But the details of the affair soon cast doubt on this account. The reservoir is not large, and some survivors might have been expected to swim to safety. Then, it emerged that the bodies of all 32 people had been found in a small cabin on the bottom deck, where passengers are not supposed to go. The Chinese imposed what amounted to a news blackout on the incident, Taiwanese journalists were banned from reporting it, and Taiwan's semi-official Straits Exchange Foundation (SEF), which deals with mainland affairs, was not permitted to send a representative to help the relatives. Retrieved November 6, 2017, from http://www.independent.co.uk/news/world/china-attemptsto-cover-up-taiwanese-boat-murders-1372048.html.

6 Taiwan Solidarity Union (TSU) was founded in 2001 and regards the ex-ROC president Lee Teng-hui as its spiritual leader. The Party advocates for Taiwan's independence and wishes to deepen the Taiwanization movement. TSU has often been considered to be much more drastic than the Democratic Progressive Party (DPP) which also advocates Taiwan's independence.
} 
word to describe the cross-strait relations in every aspect.

\section{From 2008 to Date}

The cross-strait relations made a U-turn in 2008 as Kuomintang regained power from DPP, when President Ma Ying-jeou was elected. The door to dialogue opened up soon and a historical moment came when the first direct cross-strait flight operated in December 2008.

Since then, the 1992 Consensus was re-celebrated and more than 20 agreements regarding the cross-strait trade were signed. However, Ma Ying-jeou's pro mainland policies have not been popular within the island and people seem to blame Taiwan's economic problems (high housing price, low income, food-security problems, etc.) on Ma's policies and his incompetent leadership.

Despite the political stability, Ma has faced tremendous challenges when he seeks to broaden and deepen Taiwan's economy interactions with mainland China. During the Sunflower Student Movement (J. R., 2014), protesters occupied the debating chamber of the Legislative Yuan, ROC's parliament for three weeks until Ma agreed to postpone the free trade pact in services with mainland. A few months later, the Hong Kong Umbrella Movement, which was triggered by Beijing's decision to veto the candidates before they could be nominated to run the direct chief executive election scheduled for 2017 (Ying \& Sarquis, 2014) took place. Many Taiwanese and Hong Kongnese people (especially the students and the younger generation) expressed sympathy by shouting the slogan in the social media "Don't let Taiwan become a second Hong Kong".

The following local elections held in December 2014 proved to be a landslide victory for the DPP. The DPP swept Kuomintang's seats in the local mayor offices and councils to the surprise of most critics. The results were interpreted as a punishment for Kuomintang and President Ma, although in many experts' view, it was unfair to blame Taiwan's weak position in the globalized economy totally on the recent policies (Chen, 2014). Encouraged by the victory, DPP without surprise won the presidential election in 2016 and such result again jeopardized the cross-strait relations.

Nevertheless, the confrontation between the DPP administration and Beijing has not been able to put the cross-strait relations in turmoil, given that the cross-strait commercial and cultural ties established are too hard to break and many Taiwanese people welcome the newly implemented policy which grants "quasi-citizenship" to Taiwanese residents in mainland China with the 18-digit ID number (Chung, 2018). Furthermore, DPP lost the local elections in December 2018 mainly due to failures to deliver economic improvements for Taiwan as promised in the 2014 election campaigns.

\section{Separate Identities in the Present}

\section{The Dichotomy of Autocracy and Democracy}

When it comes to discussions on violations against human rights and the media repression in mainland China, Beijing has always argued that, for China's particular characteristics, their social and historical development does not desire to imitate any foreign system: The form of communism implemented by the Soviet Union did not apply to the country; neither should the democracy led by the USA today. China needs to explore its own route.

What mainland China practices today is state authoritarianism and it seems to be effective regarding the state's economic development and political stability. While Taiwan is considered to be a role-model of democracy in the region, following the U.S. model, it is also true that the island suffers greatly from political 
turmoil under multi-party politics. The U-turn policies alternating between Kuomintang \& DPP not only due to their ideological differences but also considerations for elections have delayed Taiwan's overall development in the past two decades and put it in the lowest ranking of the four Asian dragons. The ex-Singaporean Prime Minister Lee Kuan Yew, who led Singapore's independence from Malaysia in the 1960's and successfully transformed the poor fishing village into a first world nation-city, is a firm believer of state authoritarianism and has proved to be correct, at least within the territory of Singapore. He has mentioned in various occasions that in order to have a first rate government, you need first rate talents to run the government. Without the state elites, and the citizens who respect the state mechanism and follow the discipline, a country will never have the opportunity to join in the first world club (Allison, Blackwill, \& Wyne, 2012).

In the particular case of China, Lee commented that in China's 5,000-year long history, the heads (votes) were never counted; all the rulers named themselves the emperor, the son of heaven; if you disagreed, your head would be cut instead of counted; If China becomes a liberal democracy, it will break down (Lee, 2001).

We tend to agree with Lee's point of view, but we also disagree with the total practice of state authoritarianism. In the direction of development, Singapore's experience is much valued in the region: An authoritarian government with high transparency, efficiency, and social equality is much more palatable for public opinion on the whole. It is not perfect, just as no socio-political system is perfect in the world, for instance it has never really solved the problems of racial integration between the three dominant ethnic groups (the Chinese, Malay, and the Hindu), and nowadays, it faces the challenges of immigrants from the region and their integration into Singaporean society. Furthermore, there is no comparison between the scale of China and that of Singapore. What has worked in Singapore does not necessarily apply to China's conditions. However, it is clear that Singapore ranks amongst the most successful cases of development in the world in the modern history. Another example is India: It is a country similar to China's scale and it has been a democracy since its independence from the English; it is also corrupt, inefficient, and burdened with bureaucracy. We definitely do not want to see China heading into India's direction. So, it goes back to Beijing's statement: China needs to explore its own route. And it is definitely worthwhile noting that the Chinese model accounts for the success story that China has become since the last decade of the past century, which may lead their people to feel proud to be Chinese.

\section{Diplomatic Competitions}

While the PRC replaced the ROC's position in the UN Security Council in 1971 and established official diplomatic ties with the USA, the ROC is still recognized currently as an independent Sovereign country only by 17 states in the world (Ministry of Foreign Affairs of the ROC, 2019). Most of them are in Central America, a handful is in South America, Oceania, and Africa and only one in Europe, the Vatican.

Under the One China Principle, every country has to choose between the PRC and the ROC in terms of establishing formal diplomatic relations, and the international reality is that by choosing the former you gain entry to a much bigger market and has a share in the Chinese version of Marshall Plan (Penna, 2014). The benefits are obvious, so why not?

The Holy See has different concerns. Without the purpose of conventional trades, the Holy See seeks to expand its influence as extensively as possible. For decades, after the founding of the PRC, the Vatican has always been keen on absorbing the Catholics in the Chinese mainland, estimated at some 12 million followers, in comparison to less than half a million in Taiwan (Mishkin \& Anderlini, 2013). 
However, the Vatican and Beijing have not established formal relations due to Beijing's negative attitude towards the Vatican administration. Currently, Beijing directly manages the "official" local church through the Patriotic Association, deciding episcopal appointments without regard for Vatican instructions. The "underground" church which is faithful to Rome is constantly subject to attacks, arrests, and oppression (Vatican Insider Staff, 2015). There are signs of improvement since Beijing recently approved bishop candidates from the province of Inner Mongolia and the province of Shaanxi in April this year. They were the first bishop elections since Beijing and the Vatican signed a provisional agreement on appointing bishops in September 2018 (Lau, 2019).

It is only natural for Beijing to insist on its power over the church. The Dalai Lama experience reminds Beijing of the danger of a religious leader seeking political power and the mass gathering for prayer is also unacceptable for its potential to develop into a state upheaval. As for the Holy See, considering the risks of renouncing its "universality" of the doctrinal and institutional unity of the church and the potential undermining of its "moral power" on the defense of religious freedom and other forms of human rights, there is still much to negotiate before it finally severs diplomatic ties with Taipei and normalizes relations with Beijing (Bozzato, 2017).

Regarding international organizations, both the ROC and the PRC are members of the World Trade Organization and Asia Pacific Economic Cooperation. The ROC (Taiwan) was accepted in these organizations under Beijing's consent and in most of the other major organizations or events; Taiwan is known as "Chinese Taipei".

\section{The Japan Paradox}

Japan had been China's enemy long before the beginning of WWII and Kuomintang fought against the Japanese invasion with all its resources since the early thirties. As for Taiwan, Japan's best friend in East Asia (Taiwan donated more than any other country or region to Japan after the devastating earth-quake \& tsunami that occurred on March 11th 2011, Taipei Times, 2011), a lot of people still appreciate Japan for its contribution in modernizing Taiwan.

On the contrary, throughout mainland China, people generally hold hostility against the Japanese for the war crimes committed during WWII. Most mainland Chinese find it difficult to understand why Taiwanese people (the natives, excluding the ones that arrived after 1949) highly praise Japanese culture, to the extent that many elderly people consider themselves to be almost Japanese for the education they received in their younger days. When Japan is brought to the topic, the mainland Chinese remember the pain inflicted upon them during the war but the Taiwanese think of all the great contributions of the Japanese legacy remaining in the island.

The only topics that mainland China and Taiwan share in common regarding Japan might be the "Baodiao Yundong" (Defend the Diaoyu Islands Movement) (Chen, 2009) and the sensitive issue of comfort women during the WWII. Diaoyu Islands (the Japanese name them Senkaku Islands) are claimed to be China's territory since Japan surrendered in 1945 and returned Taiwan to China as Diaoyu Islands are considered the outlying island of Taiwan. However, due to the U.S.' blurry attitudes towards the islands and the diverse sources and interpretations of the historical documents, the sovereignty of the islands remains undefined. The issue of comfort women is a shared one among all the ex-Japanese occupied countries and regions during WWII, as the women who were "in-service" mainly came from Korea, mainland China and Taiwan, it is a pending issue that requires Japan's official recognition and apologies. 


\section{The Chinese Language Orthodoxy}

Even though the ROC is only recognized officially by 17 members of the $\mathrm{UN}$, it has representative offices (often named Taipei Representative Office) in almost every corner of the world. While the Confucius Institute under Beijing expands extensively and promotes the Chinese language and culture, the Taipei office is also doing its bid.

The main differences are that Taiwan, Hong Kong, and Macau reserve officially the writing system of traditional Chinese characters, in comparison with the simplified Chinese characters in practice in mainland China. After the New China (PRC) was established, in an attempt to increase literacy, simplified Chinese characters were introduced in the 1950's and the 1960's, which were adopted by Singapore officially later and they are recognized as standardized Chinese characters nowadays.

Naturally, when a foreigner learns Chinese, he/she is given the option to study the traditional Chinese characters or the simplified Chinese characters and consequently determines to take the Chinese level test under the Taiwanese system or the mainland Chinese system. The decision matters because, in most cases, for the purpose of higher education, after receiving the scholarship from one government, you have little chances of receiving it from another government in the future. This is one strong example of how politics affects personal life.

In spite of the tremendous efforts that Beijing has made to spread its soft power, the government funded Confucius Institute, which has more than 511 institutes in 123 countries since it opened in Seoul in 2004, has faced challenges from the local communities in recent years, questioning the institute's academic freedom and transparency, especially from the developed countries (Tiezzi, 2014).

For instance, the Confucius Institute affiliated to the University of Chicago and the Confucius Institute at Pennsylvania State University both closed down in 2014. The National Association of Scholars even published a report stating the need to reexamine all the Confucius institutes in operation on U.S. campuses (Sharma, 2017).

However, there is still much to be done in the developed countries since among all the institutes, 110 are in the U.S., more than 115 are in Asia, and some 160 are in Europe. While the number in the developed world plateaus, there is great potential in other regions. The resources between Beijing and Taipei are incomparable, and in the long run, Beijing will surely solidify its status through its immense extension.

\section{Political Answers Empowered by the Economic Greater China}

Since the beginning of the century, the Chinese Mainland has shown astonishing rapid growth and it has, without question transformed itself into the commercial leader in the region. The Greater China has long become a reality, in the sense of the ever stronger commercial ties between Taiwan, Hong Kong, Macao, Singapore, and mainland China. Numerous international banking groups and consulting firms locate their Asian headquarters in the region of the Greater China, to a large extent for the convenience of an extensive Chinese-speaking population. As the World's second largest economy, the PRC has the vision to unify the major economies in the region and is promoting the RCEP (Regional Comprehensive Economic Partnership) mainly with members from the ASEAN (Association of South East Asian Nations), previously viewed as a counterbalance to the TPP (Trans Pacific Partnership) led by the USA, currently considered to be the most promising regional free trade agreement in South East Asia after U.S. withdrew from the TPP. 
Taiwan (the ROC), as a pillar in the Greater China, is supposed to be a major member in RCEP, however, the Taiwanese government seemed to be more eager to negotiate joining the TPP and putting the RCEP aside. Now that TTP has been renamed as CPTTP and signed without U.S. participation in March 2018, Taiwan finds itself in an awkward situation. The concerns are obvious, on the one hand, Taiwan considers the U.S. as a strategic partner and on the other the Taiwanese have doubts about Beijing's political intentions.

No matter how much the Taiwanese people want to change the status quo, the facts are that Taiwan has invested extensively in mainland China since the 1978 economic reforms. Although China has been losing its cheap labor incentives (from 2009 to 2014, the average salary growth in mainland China has reached more than $10 \%$ annually, and in some years peaked at $14 \%^{7}$ ) and lifting the tax incentives that used to attract foreign capital, it is transforming its industrial structure from a labor-intensive model to a technology-intensive one (China Briefing, 2013) and it is still the leading exporter to date (Statista, 2016). As a result, when China goes through a lower economic growth mainly due to the demands that have dropped significantly in the EU and the U.S. since the 2008 world financial crisis, Taiwan suffers, too.

Given that most of the Taiwanese firms which invest in mainland China are export-oriented, their revenues have plateaued (Cheng, 2016) as the Chinese exports drop which in return affects the Taiwanese economy. However, among the ones that have successfully embraced the mainland Chinese domestic market the picture looks quite the opposite (Cheng, 2016), although faced with ever stiff competition from their mainland Chinese counterparts (Horwitz, 2016).

Effectively, the Taiwanese government had encouraged its enterprises to diversify its investment in the South-East Asia region, instead of concentrating its capital in mainland China. This policy is known as "Go South" first promoted by President Lee Teng-hui in the 1990's later strengthened by President Chen Shui-bian in the first decade of this century (Chen, 2004), and currently a renewed version proposed by President Tsai Ing-wen.

However, in comparison to its neighbors, mainland China provides relatively good infrastructure and political stability, a situation that other countries in the region have failed to achieve. Despite the growing production cost and the structural reforms, which have led to a sharp decrease in Taiwan's investment in mainland China, most of the Taiwanese capital remains there (MOEAIC, 2019a; 2019b) ${ }^{8}$. Out of the capital that did extend to South-East Asia, Vietnam is the biggest destination to receive Taiwanese capital. With nearly US\$31 billion worth of investments in Vietnam, Taiwan is the fourth biggest foreign investor there, following South Korea, Japan and Singapore (Vietrade, 2017). The 2014 Anti-Chinese Riot in Vietnam hit the Taiwanese investors badly, with some 1,000 Taiwanese backed business affected (Jennings, 2014). The reality is that Taiwan suffers from the territorial disputes between mainland China and Vietnam. When the anger in Vietnam exploded, it targeted on "Chinese companies", without differentiating the Taiwanese investment from the mainland Chinese investment.

At present, with DPP back to the administration and its ideological reluctance to recognize the 1992 Consensus, the cross-strait relations once again have frozen, however, this time the chill remains only on the

\footnotetext{
7 The growth of 2014 refers to corresponding data by the third quarter recorded in mainland China. The index cited here was presented by Xie Zengyi (xie.zengyi@cass.cn), lecturer \& researcher in the Chinese Academy of Social Sciences (CASS), in table 9 of the "Conference of International Studies on China and Mexico: a permanent cultural dialogue" (Coloquio internacional de estudios chinos y mexicanos: un diálogo cultural permanente) whose topic was "The new road-map of the labor law in China, in the frame of economic development", October 8th, 9th, and 10th of 2014. Ciudad Universitaria, Coyoacán, Ciudad de México.

8 The figures vary but in general at least $70 \%$ of Taiwanese capital that invests overseas goes to mainland China every year.
} 
central official level. Surprisingly, since 2013 the percentage of Taiwanese who also recognize themselves as Chinese has risen and consequently the percentage of people who only recognize themselves as Taiwanese has dropped (NCCU, 2019). Also, another survey reveals that from 2013 to 2017, on average there are 85\% of Taiwanese who identify themselves as part of the Chinese nation (Taiwan Competitiveness Forum, 2017).

The Taiwanese Independence Movement that we witness in Taiwan today, is a demonstration of "peripheral nationalism", similar to the situation in Hong Kong, although never identical, mainly due to the fact that Hong Kong was never under the rule of the ROC, because it had been a British colony since the mid-19th century until 1997.

However, critics consider that, applying the notion of peripheral nationalism to Hong Kong, and the revival of a Hongkongese identity in recent years is clearly a counter-mobilization that aims at defending Hong Kong's autonomy, core values, lifestyle, and language (Cantonese and traditional Chinese characters) against Beijing's incorporation strategies (Fong, 2017). In the case of Taiwan, the Taiwanese identity is clearly under the ROC frame since legally Taiwan represents the ROC and the center of the dispute is the orthodoxy of the Chinese sovereignty, not the rejection of the Chinese national identity. Even the current President Tsai Ing-wen, also the President of DPP said she would handle cross-strait relations in line with the constitution of the Republic of China, a statement that essentially reflected her stance that she would not declare independence (Chung, 2017).

Beijing also exercises incorporation strategies towards Taiwan. Only this time around, Beijing bypassed the inter-governmental negotiations with Taipei and launched the "31 preference policies" (CnYES, 2018) towards the Taiwanese people. During the 19th Chinese Communist Party Congress in October 2017, Beijing introduced a new series of policies to provide even more benefits for Taiwanese people who work and study in mainland China, and these policies came into effect on February 28th, 2018 with the Taiwan Affairs Office announcement. To name just a few, on the personal level, Taiwanese are able to participate in the majority of professional certification exams in mainland China, and for the ones that were already open to Taiwanese candidates, such as medical license and teaching license, the process of certification and the application for permit to practice have been simplified. On the organizational level, Taiwanese are allowed to invest in state-owned enterprises and participate in public biddings and innovation programs in mainland China, including the "Made in China 2025 projects" (Schubert, 2018). Since September 2018, Taiwanese people who have received residence permit in mainland China, a card with 18-digit ID number the same as the mainland Chinese ID card, are eligible to apply for the same housing subsidies and public medical insurances as the mainland Chinese. This measure facilitates all kinds of activities that Taiwanese people wish to carry out in mainland China, such as purchasing and obtaining the high-speed railway tickets online, realizing on-line boarding for air travels, and registering in human resources systems for job opportunities, just as any other Chinese mainland citizen. To sum up all these new policies, Taiwanese people who live in mainland China have become "quasi PRC citizens" and they generally welcome these new measures. As a matter of fact, six out of every 10 Taiwanese who work overseas are found in mainland China, Hong Kong, and Macao (DGBAS, 2017). The actual figure should be much higher as many Taiwanese who work in mainland China continue to pay for the national labor insurance policy and the national health insurance policy of the ROC for the pensions and medical benefits that they receive and these people are not considered to be working overseas. 


\section{A Cultural Greater China: Harmony but not Uniformity}

Despite the political impasse, cross-strait interactions between the people have never stopped and they are not limited to economic exchanges and merger as we have already stated.

In the peak of the Chinese Cultural Revolution, the General Association of Chinese Culture (GACC) was funded in 1967 in Taipei to lead the Chinese Cultural Renaissance, in opposition to the devastating cultural destruction in mainland China. The GACC operates as an NGO to date and, in most cases, its chairman is the President of the ROC; the current DPP president Tsai Ing-wen is no exception. However, decades after the Chinese Cultural Revolution, the PRC strives to restore and revive the Chinese cultural heritage in Chinese mainland and the results have been more than satisfying. One of the main goals of GACC today is to promote cross-strait cultural exchange activities, despite the political disputes between the two sides.

Evidently, the ROC and the PRC share the title of China as well as many other cultural/academic assets. The title Palace Museum exists both in Beijing and in Taipei, the former preserves the original architecture of the Forbidden City and the latter has a most extensive and exquisite collection of the Chinese antiques taken from the Forbidden City and many other locations in Chinese mainland during the Chinese civil war. The title Tsinghua University is found both in Beijing and in Taiwan, the former is the original one founded in Beijing in 1911 and the latter is the one re-established in Taiwan in 1956. The "two Tsinghua Universities" hold the same motto "Self-Discipline and Social Commitment" and are among the best in the region. The same case applies for the two "Chiao Tung Universities" in Shanghai and in Taiwan. Up to date, these universities celebrate the same anniversary, build alliances, and exchange their resources, though operated separately and placed individually on international rankings.

The most successful case of "Chinese cultural unification" in recent years might be the reunified landscape painting "Dwelling in the Fuchun Mountains" painted during the Yuan dynasty and torn apart in two during the Ming dynasty. This work of art was reunified in 2011 in the National Palace Museum in Taipei under the consent of the ROC and the PRC governments. Prime Minister Wen Jiabao of PRC made a statement "If the painting can be brought together, so can our people" (Jacobs, 2011). The Chinese cultural identity is already a shared one between the Taiwan Strait today, given the recognition of the same millennial historical and cultural roots. However, in line with what McCarthy (2009) wisely observed in her studies of the Chinese ethnic groups: on the one hand, a shared cultural identity is neither an inherent or necessary basis of cohesion; on the other hand, conflict and lack of cohesion do not indicate the absence of a shared identity.

On the spiritual sphere, Fo Guang Shan and Mazu have proved to be embodiments of unbreakable spiritual connections. Fo Guang Shan, a Taiwan based Buddhist organization, is undisputedly the most renowned community for Chinese Buddhist Ritual Practice in the Greater China. Its founder and spiritual leader Master Hsing Yun, was converted in mainland China and fled to Taiwan in 1949. Until 1989, Master Hsing Yun made his great return to mainland China together with Fo Guang Shan's Humanistic Buddhism philosophy, which marked the first reencounter of cross-strait Chinese Buddhist communities in 40 years. The latest project in which Fo Guang Shan has involved itself regarding the cross-strait relations is its participation and support in the Belt and Road Asian Buddhist Forum which was significant in the sense that the cross-strait cooperation radiated beyond the Greater China.

In the realm of Taoism, Mazu, the Chinese sea goddess, is worshipped by some 20 million people in more than 5,000 temples in the Chinese Communities throughout the world (Wang, 2003), and among them, an 
estimate 800 are found in Taiwan (Lin, 2003). Mazu, also known as the tianhou (the Empress of Heaven) takes her annual tour cross-strait and around South East Asia among the Chinese communities. In 2017, the original Mazu from Meizhou, Fujian province (recognized as Mazu's birth place) made her presence in Taiwan for the second time in two decades and toured around 26 Mazu temples in the island (Taipei City Government, 2017).

It must be emphasized that Buddhism, although originally from India, has integrated into Chinese culture so successfully that in many temples, gods, goddesses and deities from both Buddhism and Taoism are found under the same roof, as if there were no divisions. This fact also serves as a strong evidence of the principle of "harmony but not uniformity" in Chinese civilization.

\section{Taipei: The Nearest City to Beijing}

The capital of the PRC is Beijing, meaning the "the Northern Capital", laid down its curtains before the whole world in the 2008 Summer Olympics. The capital of the ROC is Taipei, but before 1949, the capital of the ROC was Nanjing, meaning the "Southern Capital", and back then Beijing was known as Beiping, meaning "the Northern Peace". The name of the northern city was changed between Beijing and Beiping on many occasions in Chinese History; when the capital of the dynasty was in the south, for instance in the Ming dynasty (1368-1644), the city was addressed as Beiping; when the capital was in the north, in the case of the Qing dynasty (1644-1912), the city's name was Beijing. When Kuomintang retreated to Taiwan in 1949, many people from Beiping followed and later settled down in Taiwan, not knowing that it was to be a new home forever. As the capital of the many Chinese dynasties, Beiping had many noble families and intellectuals, all of whom enjoyed privileges and preserved the traditional Confucian doctrines; they transferred their values and way of life as they moved to Taipei, where it is recognized they have preserved most traditional Chinese cultural elements among the cities with a major Chinese community in East Asia.

The Cantonese news journal Newsweekly opened a special column that was named "Taiwan, the most beautiful scenery is its people" in 2012 and it was such a success that it was edited as a book and published in 2013 (Newsweekly Editorial, 2013). One of the most popular articles in the column was "Taipei, the neatest city to Beiping", which narrows the similarities between Taipei and Beiping and how much the modern Chinese capital Beijing has been transformed, to an extent that the elder citizens do not recognize it anymore. Taipei was voted by the readers of the Newsweekly as the "most distanced city" among the Chinese communities in 1998; 15 years later, thanks to the open policies cross the Strait, Taipei has been transformed to the "dearest city" in the vote (Yu, 2012). For one reason, many mainland Chinese found their childhood memories and even the "soul" of Beiping in Taipei.

Among the mainland visitors in Taiwan, when asked about their impression of the island, many comment that the first impression Taipei gives, is its old infrastructure and buildings, not even as developed as many second-rank cities ${ }^{9}$ in mainland China; however, as the trip comes to an end, they realize the most beautiful scenery of Taiwan is really its people, exceptionally hospitable, kind and polite in general, not like in most big cities in mainland where indifference tends to dominate. Cultural differences may tend to divide communities of the same origin, no doubt, but it is clear that there are sufficient similarities in the whole "Greater China" to speak of a unified Chinese civilization and identity.

\footnotetext{
9 The first Rank cities in mainland China are Beijing, Shanghai, Guangzhou y Shenzhen, most of the capital cities of the provinces are considered as second rank cities.
} 


\section{Conclusion}

According to Hung and Kuo (2010), the transformation of China into a modern nation-state is perhaps the most peculiar in the world history of nation formation, and in the opinion of Jacques (2011) and Zhang (2016), China has never been a European style modern nation-state and very probably will never be one.

She is proud to be a long-lasting civilization in the world today, claiming to be a "civilizational state" (Zhang, 2016). In this context, the concept of the Greater China has extended from the commercial realms to all aspects of life, alongside the political divisions. The separation of Taiwan from mainland China is more of a geopolitical accident than an inevitable fact of life. The divide between them is more due to historical circumstances than to irreconcilable differences.

The case of the Taiwan Strait bilateral relations is the embodiment of the Chinese civilizational wisdom of "harmony but not uniformity". The 1992 Consensus permits the different interpretations of the Sole China and thus provides the legitimate framework for cross-strait communications, practically in line with the ROC constitutional status quo "One China, Two Regions" which refers to the region of Mainland China and the region of Taiwan. Consequently, in different regions run different systems.

Whether the experiment of "One Country, Two Systems" has been a success in Hong Kong and Macao remains an open question, so as to whether Taiwan will be converted into "another Hong Kong" following the "One Country Two Systems" model though with substantive modifications.

Since the Chinese civil war, the cross-strait ties have never been entirely broken, and communications accelerated after the lift of the four-decade long curfew in 1987. Emotionally, culturally and even institutionally Taiwan and mainland belong to the Sole China, despite the ROC and PRC divisions. We firmly believe that the concept of the Greater China truthfully reflects the status quo and conveys the message of the shared historical and cultural roots. The comment "Taipei is the nearest city to Beiping" is also a shared one among the people cross the Taiwan Strait.

The rise of the PRC to world power has already made the economic and cultural integration of the Greater China a viable strategy and an ongoing reality. Political wisdom can, no doubt, contribute to a peaceful reaccomodation of the Chinese civilizational state that may guide the current international system closer to its point of equilibrium.

\section{References}

Allison, G., Blackwill, R. D., \& Wyne, A. (Eds.). (2012). Lee Kuan Yew: The grand master's insights on China, the United States, and the World. Cambridge, MA: Belfer Center for Science and International Affairs.

Anti-Secession Law. (2005). Retrieved November 10, 2017, from http://www.china.org.cn/english/2005lh/122724.htm

Betioli Contel, F. (2015). Concepts of region and regionalization: Aspects of its evolution and possible uses to health regionalization. Saude Soc, 24(2), 447-460.

Bozzato, F. (2017). Las relaciones de la Santa Sede con la República de China (Taiwán) y el dilema de las relaciones con la República Popular de China. Perspectiva Integral, Tecnológico de Monterrey, 5(9), 24-48.

Chen, D. D. (2014). Taiwan's DPP's election success: Brought to you by the 1992 Consensus. The Diplomat. Retrieved November 11, 2017, from http://thediplomat.com/2014/12/taiwans-dpps-election-success-brought-to-you-by-the-1992-consensus/

Chen, J. (2009). Radicalization of the protect Diaoyutai Movement in 1970s-America. Journal of Chinese Overseas, (2), $310-335$.

Chen, M. (2004). "Go South" strategy threatened. Taipei Times. Retrieved November 10, 2017, from http://www.taipeitimes.com/News/taiwan/archives/2004/09/29/2003204811

Chen, S. W. H. (2011). The gold in the Big River \& Big Sea. Apple Daily. Retrieved November 11, 2017, from http://www.appledaily.com.tw/appledaily/article/headline/20110319/33259302/ 
Cheng, T. F. (2016). Taiwanese tech companies see sales drop of 7\% in first half. Nikkei. Retrieved November 27, 2017, from https://asia.nikkei.com/Business/AC/Taiwanese-tech-companies-see-sales-drop-of-7-in-first-half?page=1

China Briefing. (2013). China's tax incentives for high-tech enterprises. China Briefing. Retrieved November 12, 2017, from http://www.china-briefing.com/news/2013/08/08/chinas-tax-incentives-for-high-tech-enterprises.html

China Times Editorial. (2012). 1992 Consensus means different interpretations: A translation. China Times Editorial. Retrieved November 10, 2017, from https://datelinetaipei.wordpress.com/2012/11/28/1992-consensus-means-different-interpretations/amp/

Chung, L. (2017). Taiwan's new premier risks Beijing's wrath after affirming support for island's independence. South China
Morning
Post.
Retrieved
November
11 ,
2017 ,
from

http://www.scmp.com/news/china/policies-politics/article/2113009/taiwans-new-premier-risks-beijings-wrath-after

Chung, L. (2018). Is Beijing's offer of residence permits to Taiwanese a trick or treat? South China Morning Post. Retrieved May 20, 2019, from https://www.scmp.com/news/china/politics/article/2164430/beijings-offer-residence-permits-taiwanese-trick-or-treat

Claval, P. (1974). L'Évolution de la géographie humaine. Paris: Les Belles Lettres.

Claval, P. (1987). The region as a geographical, economic and cultural concept. International Social Science Journal, 39(2), $159-172$.

CnYES. (2018). The full text of the 31 preference policies towards Taiwan announced by Taiwan Affairs Office. CnYES.com. Retrieved March 27, 2018, from https://news.cnyes.com/news/id/4051032

DGBAS. (2017). Report on nationals who work overseas in 2015. DGBAS. Retrieved November 11, 2017, from https://www.dgbas.gov.tw/public/Attachment/74610132VTN8T5VB.pdf

Duarte, A. C. (1980). Regionalização: considerações metodológicas. Boletim de Geografia Teorética, 10(20), 5-32.

Fong, B. C. H. (2017). One Country, Two Nationalisms: Center-periphery relations between Mainland China and Hong Kong, 1997-2016. Modern China, 43(5), 523-556.

Gao, W. Q. (2007). Zhou Enlai: The last perfect revolutionary. New York: Public Affairs.

Global Security.org. (2011). Taiwan Strait 21 July 1995 to 23 March 1996. Global Security.org. Retrieved November 12, 2017, from http://www.globalsecurity.org/military/ops/taiwan_strait.htm

Harding, H. (1993). The concept of the Greater China: Themes, variations and reservations. The China Quarterly, (136), 660-686.

Horowitz, J. (2016). The charts that show how Trump's “One China” statements could jeopardize Taiwan's economy. Quartz.

$\begin{array}{llll}\text { Retrieved November } & 27, & 2017, & \text { from }\end{array}$ https://qz.com/861507/charted-taiwans-economy-is-more-dependent-on-china-than-ever-before-making-trumps-threats-dangerous/

Horowitz, S., \& Tan, A. C. (2005). The strategic logic of Taiwanization. World Affairs, 169(2), 87-95.

Hung, H. F., \& Kuo, H. Y. (2010). "One country, two systems" and its antagonists in Tibet and Taiwan. China Information, 24(3), 317-337.

J. R. (2014). Sunflower sutra. The Economist. Retrieved November 10, 2017, from http://www.economist.com/blogs/banyan/2014/04/politics-taiwan

Jacobs, A. (2011). A reunified painting stirs big thoughts in China and Taiwan. New York Times. Retrieved November 12, 2017, from http://www.nytimes.com/2011/07/06/world/asia/06taiwan.html

Jacques, M. (2011). Civilization state versus nation-state. Süddeutsche Zeitung. Retrieved January 6, 2018, from http://www.martinjacques.com/articles/civilization-state-versus-nation-state-2/

Jennings, R. (2014). 1,000 Taiwan-backed businesses reported affected by Vietnam protests. Voice of America. Retrieved November 10, 2017, from http://www.voanews.com/content/taiwan-backed-businesses-reported-affected-by-vietnam-protests/1914955.html

Jiang, Z. H., Mi, H., \& Zhang, Y. G. (1996). The estimation of the migration from Chinese Mainland to Taiwan and other overseas destinations in the period of 1946-1949. Population Science of China, 8(4), 403-419.

Lam, L. S. (2015). Conservatism and the Kissinger-Mao Axis: Development of the Twin Global Orders. London: Lexington Books.

Lambert, R., Montagnon, P., \& Dawkins, W. (1999). Veteran Asian leaders scorns U.S. Policy. Financial Times, May $19,1999$.

Lau, M. (2019). China's acceptance of Vatican-approved bishop candidates “a positive sign". South China Morning Post. $\begin{array}{llll}\text { Retrieved } \quad \text { May 20, 2019, from } & \text { 20 }\end{array}$ https://www.scmp.com/news/china/society/article/3006460/chinas-acceptance-vatican-approved-bishop-candidates-positive

Lee, K. Y. (2001). Interview. Public Broadcasting Service, May 05, 2001.

Lin, W. H. (2003). Foreword of a guide of World Mazu Temples. Meizhou Daily Overseas Edition. Retrieved March 23, 2017, from http://www.66163.com/Fujian_w/news/mzrb1/030513/1_28.html

Long, Y. T. (2009). Big River \& Big Sea 1949 (Da Jiang Da Hai 1949). Taipei: Common Wealth Magazine Press. 
McCarthy, S. (2009). Communist multiculturalism: Ethnic revival in Southwest China, Washington: University of Washington Press.

Ministry of Foreign Affairs, Republic of China (Taiwan). (2019). Retrieved May 20, 2019, from https://www.mofa.gov.tw/AlliesIndex.aspx?n=0757912EB2F1C601\&sms=26470E539B6FA395

Mishkin, S., \& Anderlini, J. (2013). China urges Vatican to cut Taiwan ties. Financial Times. Retrieved November 11, 2017, from http://www.ft.com/intl/cms/s/0/3163ca1e-9090-11e2-862b-00144feabdc0.html\#axzz3RfGRAZcM

MOEAIC. (2019a). Investment to Mainland China. Retrieved May 20, 2019, from https://www.moeaic.gov.tw/business_category.view?lang=en\&seq=3

MOEAIC. (2019b). Outward investment. Retrieved May $20, \quad$ 2019, from https://www.moeaic.gov.tw/business_category.view?lang=en\&seq=2

NCCU. (2019). Taiwanese/Chinese identification trend distribution in Taiwan (1992/06-2018/12). Retrieved May 20, 2019, from http://esc.nccu.edu.tw/course/news.php?Sn=166

Newsweekly Editorial. (2013). Taiwan, the most beautiful scenery is its people. Beijing: China Citic Publishing House.

Penna, M. (2014). China's marshall plan: All silk roads lead to Beijing? World Politics Review. Retrieved November 13, 2017, from http://www.worldpoliticsreview.com/articles/14618/china-s-marshall-plan-all-silk-roads-lead-to-beijing

Pye, L. W. (1990). China: Erratic state, frustrated society. Foreign Affairs, Fall, 1990.

Schubert, G. (2018). China's 31 preference policies for Taiwan: An opportunity, no threat. Taiwan Insight. Retrieved April 2, 2018, from https://taiwaninsight.org/2018/03/21/chinas-new-31-preference-policies-for-taiwan-an-opportunity-no-threat/

Sharma, Y. (2017). Close Confucius institutes on US campuses, NAS says. University World News. Retrieved November 12, 2017, from http://www.universityworldnews.com/article.php?story=20170426121906298

Statista. (2016). Top 20 export countries worldwide in 2016 (in billion U.S. dollars). Statista. Retrieved November 13, 2017, from https://www.statista.com/statistics/264623/leading-export-countries-worldwide/

Taipei City Government. (2017). 2017 Northern Taiwan Matsu cultural festival. Taipei City Government. Retrieved March 23, 2018, from https://english.gov.taipei/News_Content.aspx?n=4FF938C7E036410F\&s=ABE3FDE9DE88558B

Taipei Times. (2011). Taiwan gives most in world to Japan. Taipei Times. Retrieved November 13, 2017, from http://www.taipeitimes.com/News/taiwan/archives/2011/04/16/2003500900

Taiwan Competitiveness Forum. (2017). Retrieved November 13, 2017, from http://www.tcf.tw/\%E5\%8F\%B0\%E7\%81\%A3\%E6\%B0\%91\%E7\%9C\%BE\%E5\%9C\%8B\%E6\%97\%8F\%E8\%AA\%8D\%E $5 \% 90 \% 8 \mathrm{C} \% \mathrm{E} 4 \% \mathrm{~B} 8 \% 8 \mathrm{~B} \% \mathrm{E} \% 8 \mathrm{D} \% 8 \mathrm{~A} \% \mathrm{E} 5 \% \mathrm{~B} 9 \% \mathrm{~B} 4 \% \mathrm{E} 8 \% \mathrm{AA} \% \mathrm{BF} \% \mathrm{E} 6 \% \mathrm{~F} \% \mathrm{~A} 5 \% \mathrm{E} 6 \% 96 \mathrm{~B} 0 \% \mathrm{E} 8 \% 81 \% 9 \mathrm{E} \% \mathrm{E} 8 \% \mathrm{BC}$ $\% \mathrm{AF} \% \mathrm{E} 8 \% \mathrm{~A} 6 \% 8120171018 /$

The Economist. (1987). Too rich to stay a lonely beacon. The Economist, March, 1987.

Tiezzi, S. (2014). The future of China's Confucius Institutes. The Diplomat. Retrieved November 13, 2017, from http://thediplomat.com/2014/09/the-future-of-chinas-confucius-institutes/

Vatican Insider Staff. (2015). China says yes to dialogue with the Vatican but urges it to sever ties with Taiwan. Vatican Insider. Retrieved November 13, 2017, from http://vaticaninsider.lastampa.it/en/the-vatican/detail/articolo/cina-china-china-38683/

Vietrade. (2017). Vietnam's nine-month FDI hits record of nearly US $\$ 25.5$ billion. Vietnam Trade Promotion Agency. Retrieved May 20, 2019, from http://en.vietrade.gov.vn/index.php?option=com_content\&view=article\&id=2609:vietnams-nine-month-fdi-hits-record-of-ne arly-us255-billion-\&catid=270: vietnam-industry-news\&Itemid=363

Wallerstein, I. (1976). The modern world-system: Capitalist agriculture and the origins of the European world-economy in the sixteenth century. New York: Academic Press.

Wang, F. F. (2003). The first volume of A Guide of World Mazu Temples is launched. People's Daily Overseas Edition. Retrieved March 23, 2018, from http://www.people.com.cn/GB/paper39/9038/842022.html

Weitz, R. (2012). EU should keep China Arms embargo. The Diplomat. Retrieved November 13 , 2017 from http://thediplomat.com/2012/04/eu-should-keep-china-arms-embargo/

Whitlessey, D. (1954). The regional concept and the regional method. In J. Preston and C. Jones (Eds.), American geography: Inventory and prospect (pp. 19-68). Syracuse: Syracuse University Press.

Xie, Z. (2014). The new road-map of the labor law in China, in the frame of economic development. Conference of International Studies on China and Mexico: A Permanent Cultural Dialogue, October 8, 9, and 10, Ciudad Universitaria, Coyoacán, Ciudad de México. 
Ying, W. C., \& Sarquis, D. (2014). Social protest in Hong Kong in 2014 and the possibilities of democratization in China: The actual scope of utopia. Revista Enfoques, 11(21), 87-110.

Yu, Q. (2012). Taipei, the neatest city to Beiping. Newsweekly, No. 398.

Zhang, W. W. (2016). The China horizon: Glory and dream of a civilizational state. Hackensack NJ: World Century. 